\title{
Immunoglobulin M Anti-Hepatitis A Virus Determination by Reorienting Gradient Centrifugation for Diagnosis of Acute Hepatitis A
}

\author{
G. G. FRÖSNER, R. SCHEID, H. WOLF," AND F. DEINHARDT \\ Max von Pettenkofer-Institut, University of Munich, 8000 Munich 2, Federal Republic of Germany
}

Received for publication 15 December 1978

\begin{abstract}
The persistence of antibody to hepatitis A antigen (anti-HAV) of the immunoglobulin M (IgM) class was evaluated in 88 sera of 51 acute hepatitis A patients. IgM was separated from IgG by a 2 -h reorienting sucrose gradient ultracentrifugation, and the titer of anti-HAV was determined in the IgG- and IgM-containing fractions by solid-phase radioimmunoassay. IgM anti-HAV was the predominating antibody at onset of jaundice and persisted in these patients for at least 60 days, but not longer than 115 days. The demonstration of IgM anti-HAV is therefore a valuable tool for the diagnosis of recent hepatitis $\mathrm{A}$ infection.
\end{abstract}

Particles with an average diameter of 27 to 29 $\mathrm{nm}$ found in human stool specimens have been shown to be the etiological agent of hepatitis A infection (2). Recently, according to nucleic acid and physical data, this virus could be classified as a picornavirus $(10,11)$, as already suggested by Provost and co-workers (8). Different methods such as radioimmunoassay $(4,9)$, immune adherence (6), and complement fixation (7) have been used to detect antibody to hepatitis $A$ antigen (anti-HAV). These antibodies can be found by radioimmunoassay in all cases of hepatitis $\mathrm{A}$ after onset of jaundice, and absence of anti-HAV at this stage of the disease excludes hepatitis A (3). Because of the rapid increase in antibody titer during the first 2 weeks of illness, frequently no significant further increase in titer can be found if the first serum is drawn late in the course of the disease.

The presence of anti-HAV of the immunoglobulin M (IgM) class (IgM anti-HAV) has been shown in acute- and convalescent-phase sera from human hepatitis A cases and from experimentally infected chimpanzees by testing of IgG- and IgM-containing serum fractions obtained by molecular-sieve column chromatography by radioimmunoassay (1). In serial serum specimens from 10 patients, IgM anti-HAV was separated from anti-HAV of the IgG class (IgG anti-HAV) by sucrose gradient ultracentrifugation and determined by solid-phase radioimmunoassay (5). It was concluded that IgM antiHAV is present in acute hepatitis A in low titer, but it may persist for almost 100 days after the appearance of dark urine. Therefore, the demonstration of IgM anti-HAV may serve as a diagnostic marker for acute hepatitis $\mathrm{A}$ infection.
In this paper the persistence of IgM anti-HAV is evaluated by using a less time-consuming reorienting sucrose gradient ultracentrifugation method for the separation of IgG and IgM.

\section{MATERIALS AND METHODS}

Sera. Fifty-six sera were collected 0 to 200 days after onset of jaundice from 19 patients during an epidemic of hepatitis A in Gomaringen (4) and during another outbreak in Neckartailfingen, Germany. In all patients the diagnosis of hepatitis A was confirmed by a more than fourfold increase in anti-HAV titer in a solid-phase radioimmunoassay inhibition test (4). Thirty-two additional sera were collected within $\mathbf{4 0}$ days after onset of jaundice from patients suspected of having hepatitis A according to epidemiological and clinical data.

Determination of IgM anti-HAV. IgM was separated from IgG by reorienting gradient centrifugation (12), using a TV 865 rotor (DuPont Instruments, Newton, Conn.) and a Kontron centrifuge model TGA 50 (Zürich, Switzerland). A 50- $\mu$ l amount of serum was layered on top of a $4-\mathrm{ml}$ linear 5 to $35 \%$ (wt/wt) preformed sucrose gradient in SABAG buffer (Testerub, Röhm Pharma GmbH, Darmstadt, Germany) and covered with $0.3 \mathrm{ml}$ of mineral oil (Merck, Darmstadt, Germany, no. 7174). After $2 \mathrm{~h}$ of centrifugation (50,000 rpm at $4^{\circ} \mathrm{C}$ ), 12 to 13 fractions were collected from the bottom of the tube. In each fraction the titer of antiHAV was determined by a solid-phase radioimmunoassay inhibition test, which has been described elsewhere (4).

\section{RESULTS}

Figure 1 shows the typical results of a titration of anti-HAV from the fractions of four sera obtained from patient GBM which were collected $0,9,57$, and 193 days after onset of jaundice. At day 0 (serum I) peak anti-HAV activity was found in fractions 2 and 3 . This corresponds 


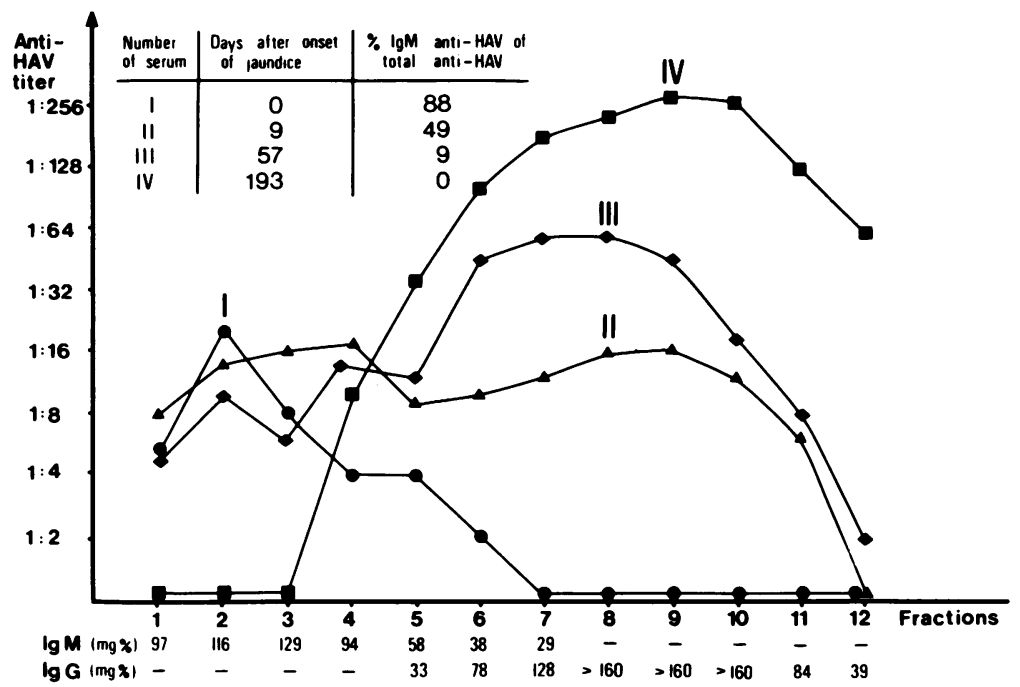

Fig. 1. Reorienting sucrose gradient ultracentrifugation of four sera from patient GBM obtained at different times after onset of hepatitis A. Anti-HAV titers determined by radioimmunoassay are given for all serum fractions in addition to the concentrations of IgM and IgG from fractions of serum I. The relative amounts of IgM anti-HAV were approximated by dividing the sum of the anti-HAV titers of fractions 1 through 4 by the sum of the titers of all fractions multiplied by 100 to equal the percent IgM anti-HAV of total anti-HAV.

with the peak concentrations of IgM determined by radial immunodiffusion (Partigen, Behringwerke AG, Marburg, Germany). Fractions 1, 4, 5 , and 6 also showed low anti-HAV activity and low IgM levels.

IgG was detected in fractions 5 through 12 , with peak concentrations in fractions 8, 9, and 10. In serum IV, collected 193 days after onset of illness, the anti-HAV titers were closely parallel to the IgG concentrations. A low anti-HAV titer was also found in fraction 4, which was usually devoid of antibody activity whenever lower- and medium-titered sera from patients with past hepatitis $A$ infections were tested.

Addition of an equal volume of $0.2 \mathrm{M}$ mercaptoethanol for $45 \mathrm{~min}$ at $37^{\circ} \mathrm{C}$ reduced the antibody activity in fraction 2 more than eightfold in serum I but did not change the antibody titer in fraction 8 of serum IV. The data suggest that antibody found in fractions 1,2 , and 3 , and to some extent in fraction 4 , belongs to the IgM class, whereas anti-HAV in fractions 5 through 12 is mainly of the IgG class. To obtain a rough estimate of the percentage of IgM anti-HAV present at different stages of the disease, the antibody titers of fractions 1 through 4 were added and expressed as a percentage of the sum of the antibody titers of all fractions (Fig. 1, Table 1).

At 0 to 5 days after onset of jaundice, between 29 and $100 \%$ (mean value, $54 \%$ ) of the anti-HAV
TABLE 1. Persistence of anti-HAV of the IgM class

\begin{tabular}{cccc}
\hline $\begin{array}{c}\text { Days after on- } \\
\text { set of jaundice }\end{array}$ & $\begin{array}{c}\text { No. positive } \\
\text { for IgM anti- } \\
\text { HAV/no. } \\
\text { tested }\end{array}$ & $\begin{array}{c}\text { \% IgM } \\
\text { anti-HAV } \\
\text { of total } \\
\text { anti-HAV } \\
\text { (mean) }\end{array}$ & $\begin{array}{c}\text { Variation of } \\
\text { IgM anti-HAV } \\
\text { as \% of total } \\
\text { anti-HAV }\end{array}$ \\
\hline $0-5$ & $20 / 20$ & 54 & $29-100$ \\
$6-10$ & $24 / 24$ & 42 & $21-67$ \\
$11-20$ & $9 / 9$ & 29 & $23-40$ \\
$21-40$ & $9 / 9$ & 24 & $14-41$ \\
$41-60$ & $9 / 9$ & 15 & $5-21$ \\
$61-80$ & $3 / 6$ & 5 & $0-17$ \\
$81-120$ & $2 / 8$ & 3 & $0-14$ \\
$>120$ & $0 / 3$ & 0 & 0 \\
\hline
\end{tabular}

present was of the IgM class (Table 1). The percentage of IgM antibody decreased with time after onset of jaundice. Between days 41 and 60, 5 to $21 \%$ anti-HAV was of the IgM class. Between days 61 and 120, only some of the sera, and after 120 days no sera, were IgM anti-HAV positive. The serum with the longest persistence of IgM anti-HAV (115 days) was drawn from a patient (SH) with elevation of serum transaminases for more than 3 months.

\section{DISCUSSION}

Frequently no significant increase in titer of anti-HAV can be detected if the first serum is drawn late in the course of hepatitis A. Therefore, the demonstration of anti-HAV of the IgM 
class may be a valuable tool for the diagnosis of a fresh hepatitis $A$ infection.

IgM was separated from IgG by reorienting gradient ultracentrifugation, and the titer of anti-HAV was determined in the different fractions. This method has considerable advantage over conventional sucrose gradient centrifugation in swinging-bucket rotors. The procedure is far less time consuming, due to the fact that first, the centrifugation time is shorter $(2 \mathrm{~h}$ instead of 16 to $20 \mathrm{~h}$ ) and, second, the rotor used (TV 865) has a capacity of eight tubes as compared to three to, maximally, six tubes in conventional swinging-bucket rotors. As a consequence, the running time is no longer a limiting factor, and 16 to 24 samples can be set up, run, and harvested per day using one centrifuge. Moreover, the separation in this special fixedangle rotor is at least as good as in a long-column swinging-bucket rotor. The determination of titers after separation of immunoglobulins by different sedimentation behavior is also a very sensitive method, because no competition between IgG and IgM antibody for the antigen takes place, as may be found in IgM-specific radioimmunoassay or in immunofluorescence methods. One objection to this method is the possible occurrence of false-positive results for IgM antibody by IgG aggregates. However, this was not observed in our study and can be controlled by evaluating antibody titers with and without treatment of the fractions with mercaptoethanol.

According to this technique, at 0 to 5 days after onset of jaundice more than half of the total anti-HAV present belonged to the IgM class, and it was found to persist for up to 60 days in every case. In sera collected between 60 and 100 days after onset of jaundice it was present in the serum of part of the patients in low titers. The patient in whom the longest persistence of IgM anti-HAV was demonstrated (115 days) also had elevated transaminases for more than 3 months. It may be that IgM antiHAV persists somewhat longer in more severe or prolonged cases of hepatitis A, but this needs further study. Nevertheless, sera of all cases obtained 120 days after onset of jaundice had anti-HAV of the IgG class only, which makes the demonstration of IgM anti-HAV a good marker for the rapid diagnosis of a fresh hepatitis A infection from a single serum sample drawn during the acute or convalescent stage of the disease.

Reorienting sucrose gradient centrifugation with subsequent testing of fractions for anti-
$\mathrm{HAV}$ is a very reliable and sensitive method for the detection of specific antibody of the IgM class. However, still less cumbersome methods should be developed for routine testing of clinical specimens.

\section{ACKNOWLEDGMENTS}

We thank V. Messelberger for excellent technical assistance.

This work was supported by the Bundesministerium für Jugend, Familie und Gesundheit (IA 2-5/176295) and by the Deutsche Forschungsgemeinschaft (Fr 400/6).

\section{LTERATURE CITED}

1. Bradley, D. W., J. E. Maynard, S. H. Hindman, C. L. Hornbeck, H. A. Fields, K. A. McCaustland, and E. H. Cook, Jr. 1977. Serodiagnosis of viral hepatitis A: detection of acute-phase immunoglobulin $\mathbf{M}$ anti-hepatitis A virus by radioimmunoassay. J. Clin. Microbiol. 5:521-530.

2. Feinstone, S. M., A. Z. Kapikian, and R. H. Purcell. 1973. Hepatitis A: detection by immune electron microscopy of a viruslike antigen associated with acute illness. Science 182:1026-1028.

3. Frösner, G. G. 1977. Nachweis von Hepatitis-A-Antigen und Antikörpern zur Diagnose der Hepatitis-A-Infektion. Muench. Med. Wochenschr. 119:825-829.

4. Frösner, G. G., L. R. Overby, B. Flehmig, H.-J. Gerth, H. Haas, R. H. Decker, C.-M. Ling, A. J. Zuckerman, and H.-R. Frösner. 1977. Seroepidemiological investigation of patients and family contacts in an epidemic of hepatitis A. J. Med. Virol. 1:163-173.

5. Locarnini, S. A., A. A. Ferris, N. I. Lehmann, and I. D. Gust. 1977. The antibody response following hepatitis A infection. Intervirology 8:309-318.

6. Miller, W. J., P. J. Provost, W. J. McAleer, O. L. Ittensohn, V. M. Villarejos, and M. R. Hilleman. 1975. Specific immune adherence assay for human hepatitis $\mathrm{A}$ antibody. Application to diagnostic and epidemiologic investigations. Proc. Soc. Exp. Biol. Med. 149: 254-261.

7. Provost, P. J., O. L. Ittensohn, V. M. Villarejos, and M. R. Hilleman. 1975. A specific complement-fixation test for human hepatitis A employing CR 326 virus antigen. Diagnosis and epidemiology. Proc. Soc. Exp. Biol. Med. 148:962-969.

8. Provost, P. J., B. S. Wolanski, W. J. Miller, O. L. Ittensohn, W. J. McAleer, and M. R. Hilleman. 1975. Physical, chemical and morphological dimensions of human hepatitis A virus strain. Proc. Soc. Exp. Biol. Med. 148:532-539.

9. Purcell, R. H., D. C. Wong, Y. Moritsugu, J. L. Dienstag, J. A. Routenberg, and J. D. Boggs. 1976. A microtiter solid-phase radioimmunoassay for hepatitis $A$ antigen and antibody. J. Immunol. 116:349-356.

10. Siegl, G., and G. G. Frösner. 1978. Characterization and classification of virus particles associated with hepatitis A. I. Size, density, and sedimentation. J. Virol. 26:4047.

11. Siegl, G., and G. G. Frösner. 1978. Characterization and classification of virus particles associated with hepatitis A. II. Type and configuration of nucleic acid. J. Virol. 26:48-53.

12. Wolf, H. J., G. G. Frösner, and F. Deinhardt. 1979. Method for rapid separation of immunoglobulin $\mathbf{M}$ from immunoglobulin $\mathrm{G}$ antibodies by using reorienting gradients in vertical rotors. J. Clin. Microbiol. 9:544-546. 